of wine, which had to be changed twice, in a cask of suitable size. The specimen arrived in very good condition, and is now stuffed and mounted.

It belongs to a species apparently allied to Platystoma truncatum, but differing in the width of the bands of teeth in the upper jaw and palate; moreover it has the barbels much shorter than any of the other known species. I propose to name it

\title{
Platystoma gigas.
}

D. 1/6. A. 11. The upper jaw projects conspicuously beyond the lower. The length of the head is contained thrice and two thirds in the total length (without caudal). Head covered with skin; maxillary barbels much shorter than the head, mandibulary barbels still shorter. The intermaxillary band of teeth is rather broader than the vomerine portion of the band on the palate, which has a crescentic form ; the intermaxillary and palatine bands are separated from each other by a very narrow interspace. The dorsal fin commences midway between the end of the snout and the origin of the adipose fin, and its first ray is rather feeble; the length of the adipose fin equals that of the anal. Caudal deeply forked. Colour of a uniform greyish brown, darker above than below.

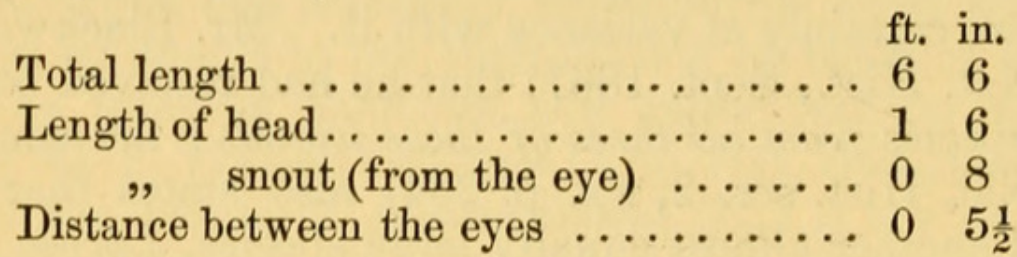

LXVII.-Description of some new Species of Birds in the National Collection. By R. Bowdler Sharpe, F.L.S., F.Z.S., \&c., Senior Assistant, Zoological Department, British Museum.

\section{Family Paridæ.}

\section{Subfamily SITTIN}

\section{Sitta tephronota, n. sp.}

S. similis S. Neumayeri, sed rostro longiore, coloribus conspicue pallidioribus, et linea nigra per oculum ducta usque ad interscapulium extensa distinguenda.

The large Nuthatch from Central Asia appears to me to be worthy of specific separation from the typical S. Neumayeri of Europe (S. syriaca, Ehr.). In the 'Birds of Europe,' Mr. Dresser and myself examined a bird from Kokand, which differed extraordinarily in size from the typical Grecian and 
Palestine specimens. I do not think, however, that the species will rest so much on the larger dimensions, as they seem to be very variable, as upon the clear pale grey coloration and the pronounced elongation of the black eye-stripe. Two specimens from Candahar in the National Collection appear to belong to the eastern form. The comparative measurement of the Kokand example with another of the true $S$. Neumayeri gave me the following results :-

Long. tot. culm. alæ. caudæ. tarsi.

$\begin{array}{lllll}\text { S. tephronota } \ldots \ldots \ldots .6 .6 .0 & 0.75 & 2 \cdot 9 & 1 \cdot 85 & 0 \cdot 9 \\ & 1 \cdot 0 & 3 \cdot 5 & 2 \cdot 1 & 1.05\end{array}$

\section{Family Muscicapidæ.}

\section{Diaphorophyia Blissetti, n. sp.}

$D$. supra saturate cinereus, vix viridi lavatus: tectricibus alarum remigibusque nigricantibus, extus viridi-cinereo marginatis: cauda supra metallice viridi, subtus nigricante: genis et regione parotica læte castaneis, plagam conspicuam triquetram formantibus: gula sordide at metallice viridi : corpore reliquo subtus pure albo, lateribus fuscescentibus nigro striolate lavatis : caruncula conspicua orbitali erecta scarlatina: rostro nigro: pedibus saturate brunneis.

Hab. Gold Coast. Presented by Andrew Swanzy, Esq.

Of this beautiful little Flycatcher I have another specimen, in my own collection of African birds, which is apparently the adult male; it differs from the one above described in having a dark metallic green back. This bird was sent to me by my friend Mr. H. F. Blissett, who procured it on the Gold Coast, in the province of Wassaw; and I have great pleasure in offering him a public acknowledgment for the aid he has rendered me by collecting birds in Western Africa.

\section{Family Timaliidæ.}

\section{Trichastoma rufipennis, n. sp.}

$T$. similis T. fulvescenti (Cass.), sed multo minor, et pileo brunneo, dorso rufescente lavato, remigibus extus sordide castaneis distinguenda. Long. tota 5.3 poll. Angl., culm. 0.55, alæ 2.45, caudæ $2 \cdot 3$, tarsi $1 \cdot 0$.

Hab. Gaboon. Collected by Mr. Paul Du Chaillu.

There can be no doubt, as Lord Walden some time ago pointed out to me, that the genera Illadopsis of Heine and Trichastoma of Blyth are identical; and the other African species are Trichastoma fulvescens (Cass.) and T. gularis (Sharpe). The present species is distinguished from both these last-named birds by its small size and red wings. 


\section{$2 \mathrm{BHL}$ Biodiversity Heritage Library}

Sharpe, Richard Bowdler. 1872. "LXVII.-Description of some new species of birds in the national collection." The Annals and magazine of natural history; zoology, botany, and geology 10, 450-451. https://doi.org/10.1080/00222937208696738.

View This Item Online: https://www.biodiversitylibrary.org/item/81231

DOI: https://doi.org/10.1080/00222937208696738

Permalink: https://www.biodiversitylibrary.org/partpdf/63355

\section{Holding Institution}

Smithsonian Libraries

\section{Sponsored by}

Smithsonian

\section{Copyright \& Reuse}

Copyright Status: Public domain. The BHL considers that this work is no longer under copyright protection.

This document was created from content at the Biodiversity Heritage Library, the world's largest open access digital library for biodiversity literature and archives. Visit BHL at https://www.biodiversitylibrary.org. 